\title{
ネットワーク・ピクセルアレイ型の地理情報を用いた住区内街路網評価システム Analysis System for Residential Street Networks Using the Geographical Database of Network and Pixel-Array Model ${ }^{1}$
}

三谷哲雄 $^{2} \cdot$ 山中英生 ${ }^{3} \cdot$ 青山吉隆 $^{3}$ Tetsuo MITANI, Hideo YAMANAKA and Yoshitaka AOYAMA

\section{1.はじめに}

住宅地区の街路網は交通基盤としての網機能とと もに市街地基盤として街路に接する宅地を支える機 能を有している。したがって、住宅地区の街路網評 価では、一般に個々の道路レベルの交通安全性や道 路環境の望ましさの評価とともに、街路沿道の宅地 レベルの市街地形成への影響や防災性など周辺市街 地における住環境の評価が必要になる。

交通ネットワーク分析では、交通ゾーンと街路 ネットワークによる地理的構造を基本とする場合が 多い。この場合、一定の規模を持ったゾーンの内部 属性は均一と仮定されており、またゾーンとネット ワークリンクの連結関係は、ゾーン中心とネット ワークノードの対応しか持たない。このため、周辺 市街地における街路網性能の評価を分析することは 難しい。一方、一般のＧＩＳでは宅地レベルの効果 計測のために土地形状をポリゴンデータとして扱っ ているが、複雑な幾何計算を要するという問題が 残っている。

そこで本研究では、周辺市街地の地理的構造を細 かなピクセルの集合として捉えることで、住区内の ネットワークを、それが形づくる市街地に及ぼす影 響を考慮して、簡便に評価するシステムを開発した。 そして、徳島市の非計画的市街地における細街路網 評価に対して、このシステムを活用した計算方法や 結果の提示方法を示し、その場合の特徴や問題点な どを検討する。

1キーワード : 住宅地区、街路網評価、地理情報システム 細街路

2学生員工修 徳島大学大学院生産開発工学専攻

3 正会員 工博 徳島大学工学部建設工学科 ₹770徳島市南常三島町 $2-1$ TEL(0886-56-7350)/FAX (0886-56-7351)

\section{2.ネットワークデータベースシステム}

(1)ネットワーク・ポリゴン型データモデルの問題

一般に用いられているＧＩＳでは、地理情報は表 -1のようにネットワーク、ポリゴン、ポイントの 3つの形状構造で表現されている。

このようなポリゴンを用いた場合、ネットワーク とポリゴンの間の近接関係の検索やポリゴン間の重 なり等の計算を行う必要がある。こうした幾何計算 の方法は、数多く開発されている。しかし、以下の ような問題を有する。

(1)ネットワークと周辺土地区画との隣接関係の検 索には両者の関連付けの基本演算が必要となるが、 こうしたリンク集合のボロノイ領域作成とポリゴン 間演算には、複雑で大量の計算処理が必要になる。

(2)特に時系列デー夕を扱う場合、座標入力精度の ために同一点の座標が入力誤差などを持つことが多 く、ポリゴン計算ではこれらの処理に複雑な判定が 必要になる。

\section{(2)ネットワーク・ピクセルアレイモデルの特徵}

本研究では、施設や土地利用の情報を持ったポイ ントやポリゴンのデー夕を、図ー 1 のように地区を 覆う細かなピクセルの属性に変換する方法を用いる ことにした。このピクセルは、その周辺の方形領域 を代表すると考えられる。このことから、地理情報 をネットワーク、ピクセルの 2 つの形状要素のみで 表すことになる。このシステムを本研究では、ネッ

\begin{tabular}{|c|c|}
\hline テータ形状 & 地理情報 \\
\hline ネットワーク & 道路網 \\
\hline ポリゴン & $\begin{array}{l}\text { 行政区、施設形状、土地利用境界線（市街 } \\
\text { ・地・非可住地など）、地形形状（河川、山 } \\
\text { 林など）等 }\end{array}$ \\
\hline ポイント & 施設代表点、行政区代表点等 \\
\hline
\end{tabular}


トワーク・ピクセルアレイモデルと呼ぶ。

このデータモデルを用いることで、計算処理等に 以下のような特徵を有する。

(1)幾何計算が簡便である。土地利用属性を持つピ クセルとネットワークを構成するリンクとの間の近 接関係は、ピクセル座標を使った距離計算で求めら れる。

(2)ピクセルを均質なコニ忙して捉えているため、 その集計の考え方が明解である。例えば特定な利用 のなされている土地面積の算定や各ピクセルに生じ た効果の算定などは、ピクセル数を集計することで 算定できる。

(3)時系列デー夕を統一的に扱える。土地利用情報 の時系列変化は、各ピクセルごとにその対応を取る ことができるので、ピクセル属性変化として統一的 に扱える。

一方、ポリゴン情報をピクセル情報に変換するこ とによる問題点としては、一般に土地の面積や空間 分布の精度がポリゴンモデルに比べて劣ることがあ げられる。ただし、ピクセル密度を大きくすること で、その精度を向上させることはできる。このよう なピクセルの密度について、本研究では以下のよう に想定した。すなわち、「計画図や評価結果を出力 する縮尺の図面において、ピクセルの色分け図等を 表示した時、それがほぼ測地的なデータを表示した 画像、すなわち、地物の形状を明示してその図上に 統計情報を表示した画像、として見える程度の密度 を持つこと」と設定した。一般に出力図面をその画 像として識別可能な最低限度のピクセル数は綎横約 $100 \times 100$ ピクセル程度であることから、例えば $100 \mathrm{~h}$ a 程度の地区を扱う住区街路網計画では、おおよそ $10 \mathrm{~m} \times 10 \mathrm{~m}$ 程度がピクセルの最大サイズと言える。

(3)ネットワーク・ピクセルアレイ型データベースの 作成方法

図ー2に、データベース構築の流れ図を示す。

住宅地図あるいは都市計画図に道路中心線、施設 代表点、市街地・用途地域区分などの土地利用区分 の境界線、これらを記入したベースマップを作成す る。図ー 3 にベースマップの概念図を示す。住宅地 図は、道路や土地の形状、土地種別（住宅・田畑な ど）が比較的簡単に認識できるという特徴を持つが、

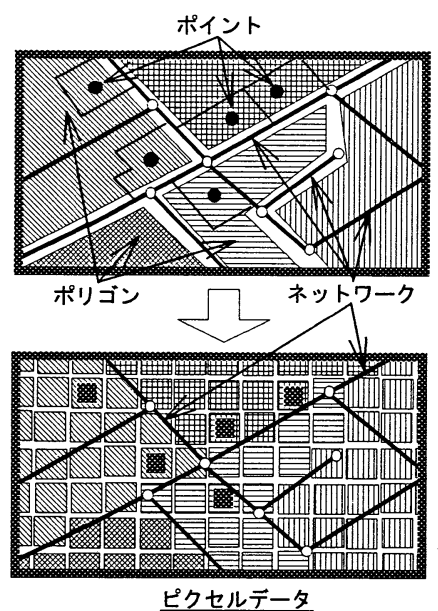

図ー1 ネットワーク・ピクセルマレ型テータへの变換

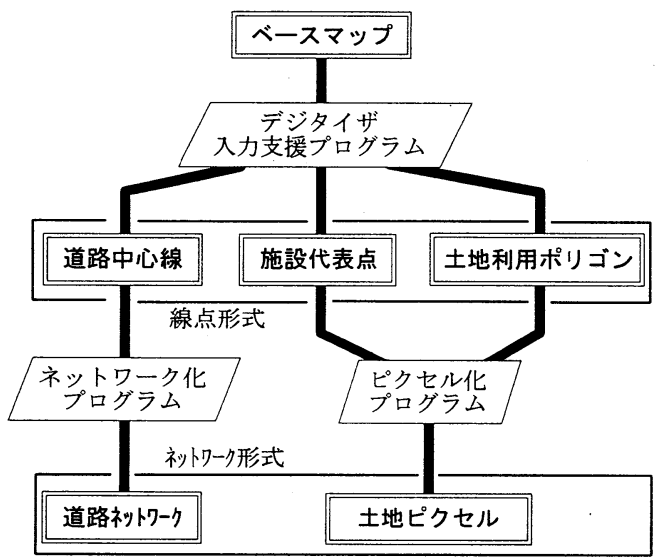

図-2 テータベース構築の流れ

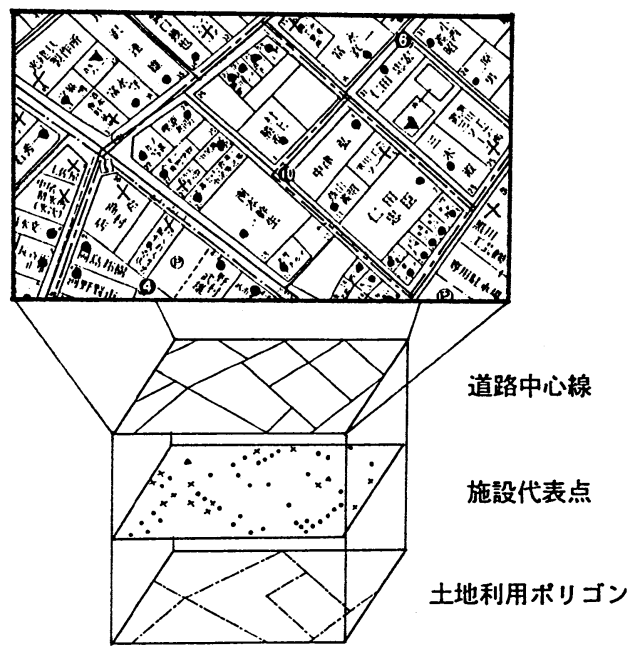

図ー3 ベースマップの概念図 
道路や敷地の認識が不確実であり、ベースマップ作 成上ページの切れ目が一致しないなどの問題を有す る。しかし、線や点で表す道路中心線や土地利用境 界線、施設代表点の位置を入力する上では、住宅地 図の持っているある程度の誤差は許容される。ただ し、街路幅員などの属性については別途道路台帳な どから入力することで対処できる。

このベースマップをデシタイザによって線と点と で構成されたデータ形式（線点形式と呼ぶ）で入力 する。道路データは、線点形式デー夕から種々の ネットワーク計算が可能な形式に変換する。施設代 表点は、入力したポイントデータとピクセルデータ とのマッチングを行い、施設情報をピクセルデータ の属性として変換する。土地利用ポリゴンは、その 境界線の頂点座標を入力し、それをピクセルデータ に変換する。この時、各ピクセルの属性は、ポリゴ ンの土地利用情報を持つか否かの $0 、 1$ 情報として 作成する。

各データモデルが持つ属性を表- 2 に示す。ネッ トワークデータの属性は、それを構成する各リンク ごとに入力する。ピクセルは、施設および土地利用 の属性を持つ。土地利用の属性については、入力す る土地利用ポリゴンの種類によって様々な属性を持 つことができる。

\section{(4)応用ソフトゥェアによる計算例}

応用ソフトウェアとしては、街路リンクとピクセ ルとを関連付けるプログラムやネットワーク計算プ ログラムを開発した。

ピクセルとリンクとの関連付けは、各ピクセルの 座標からすべてのリンクに下ろした垂線長さが最む 短いリンクをそのピクセルの最寄りリンクとして関 連付ける。これには、線分と点の距離計算を全ての リンク・ピクセル間について行う単純なプログラム を用いている。図ー4 は、各リンクの最寄りピクセ ルを表したもので、ネットワークの近似的なボロノ イ領域図と言える。

ネットワーク計算プログラムでは、ピクセルから 特定街路や特定施設などへの最短経路の探索や最短 アクセス時間、アクセス距離、折れ曲がり回数など のアクセス特性値の計算が可能である。これには、 ダイクストラ法等の最短経路探索を用いている。図
- 5 は、各ピクセルから幹線街路への最短経路を進 んだときのアクセス時間別のピクセルの空間分布図 を示したものである。

\section{3. システムの適用事例}

\section{(1)非計画的市街地における細街路網評価}

一般に非計画的市街地の街路網に関する共通な問 題点として、狭隘道路の存在や地区の骨格的街路の 不足があげられる。こうした問題に起因して、地区 の交通環境上の問題や住環境の問題、また災害時の

\begin{tabular}{|c|c|c|c|}
\hline \multicolumn{4}{|c|}{ 表-2 データの属性 } \\
\hline データモデル & \multicolumn{2}{|c|}{ 地理情報 } & 付属属性 \\
\hline ネットワーク & & 路 & $\begin{array}{l}\text { 幅員、道路の格、路線価、用途 } \\
\text { 地域区分など }\end{array}$ \\
\hline \multirow[t]{2}{*}{ ピクセル } & & 設 & 建物の種別や世帯数など \\
\hline & \multicolumn{2}{|c|}{ 土地利用 } & 市街地、用途地域など \\
\hline
\end{tabular}

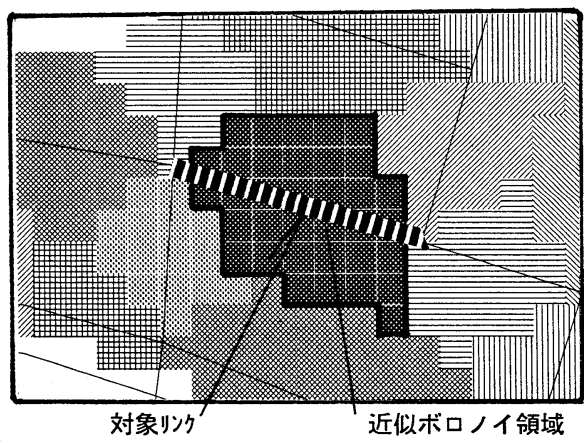

図-4 リンクとピクセルの近接関係

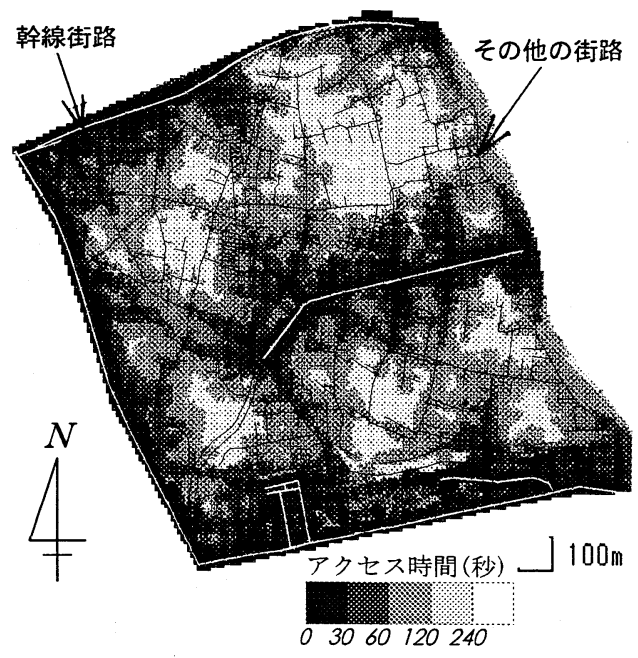

図-5 幹線街路への7クセス時間別ピクセル空間分布 
表－3 分析対象地区（1991年次）

\begin{tabular}{|c||c|}
\hline 対象地区(市街化率*) & 市街化段階 \\
\hline \hline 名東 $(39 \%)$ & スプロール初期 \\
\hline 矢三 $(57 \%)$ & スプロール中期 \\
\hline 沖洲 (58\%) & スプロール末期 \\
\hline 津田(60\%) 吉野(68\%) & 密集市街地 \\
\hline
\end{tabular}

*)都市的末利用地以外の道路を除く面積の地区面積に対 する割合を示す。

避難活動や緊急自動車の進入の困難さなどの問題を 引き起こしている。

そこで、本研究ではこうした住区内街路網の問題 に対して、市街地分布を考慮して街路網を評価する ために先のシステムを適用した。具体的には、市街 地環境の 1 つの側面である防災性の視点から、徳島 市内の非計画的市街地における細街路網の実態分析 を例に、本システムを用いた場合の計算方法やその 結果を示す。

\section{（2）分析対象地区と分析に用いたデータ}

分析対象地区は、表一 3 に示すように市街化段階 の異なる 4 地区を選定した。さらに、名東、矢三、 沖洲地区については、細街路形成や市街地形成など が街路網評価に及ぼす影響を検討するため、1991年 の前後 $4 \sim 10$ 年間隔で合計 3 時点を対象とした。

各地区について、1991年の住宅地図を基にベース マップを作成し、図ー6に示すような街路網および 土地利用データを入力した。街路網属性は、徳島市 現況平面図(縮尺1/500)から道路幅員を図上計測して 各リンクに属性として入力した。一方土地利用デー 夕は、地区内の田畑、空き地など都市的利用がなさ れていない土地区画（未利用地と呼ぶ）の境界線 （ポリゴン）を住宅地図上で判断し入力した。これ を、地区全体を覆うピクセルの属性として変換した。 1 ピクセルのサイズは $10 \mathrm{~m} \times 10 \mathrm{~m}$ とした。したがっ て、ここでは、ネットワークを構成する各リンクの 幅員属性と各ピクセルの市街地か未利用地かの属性 （市街地属性と呼ぶ）を用いることになる。

また、1991年以外の地区データは、リンクやポリ ゴンデータの編集プログラムを開発することで、 1991年次のデータベースに街路リンクや土地利用ポ リコンを計算機上で追加したり、削除することで作 成した。

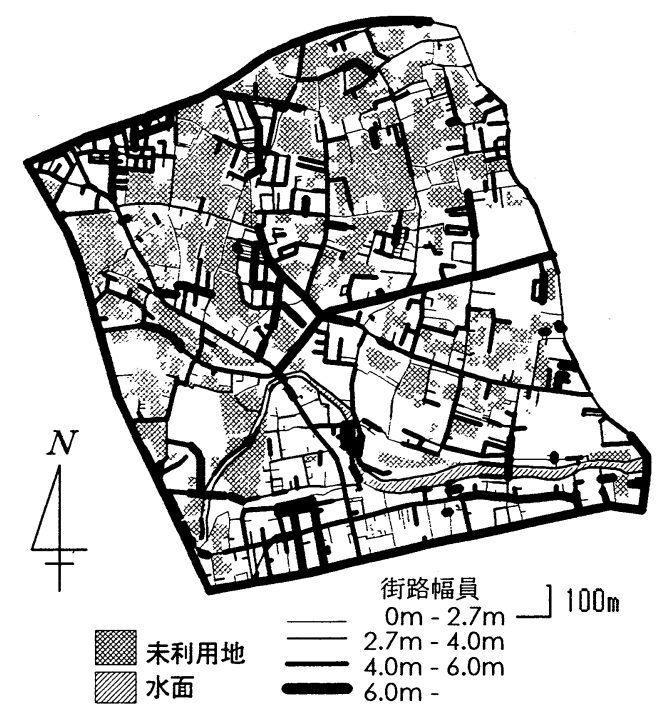

図ー6 分析に用いた街路網および土地利用データ

\section{（3）ピクセル前面街路幅員}

ピクセル前面街路とは、ネットワークとの近接関 係の情報から特定したピクセルの最寄りリンクのこ とである。図-7 7 、前面街路幅員ランク別の土地 面積構成比の例を示したものである。この例からは、 密集市街地の津田では、市街地のうち約 $40 \%$ が $4.0 \mathrm{~m}$ 未満の狭湓街路に面しており、スプロール化の遅 かった名東では、その割合は $30 \%$ 程度であることが わかる。

いまピクセルから前面街路への直線距離が当該年 次から次年次にかけて短くなった場合、そのピクセ ル周辺で街路が形成されたことになる。したがって、 各ピクセルについて、この距離が短くなったとき街 路形成有り、変化がないとき街路形成無しと判断し て、その時の土地面積を集計する。図一8は、街路 形成のあったピクセルについて、1987年から1991年 および1991年から1993年にかけての、街路形成前と 形成後それぞれの前面街路幅員ランク別構成比を示 した例である。この例からは、どちらの年次間の街 路形成を見ても幅員 $4 \mathrm{~m}$ 未満の街路に面していた土 地周辺に街路形成が見られ、幅員 $4 \mathrm{~m} \sim 5 \mathrm{~m}$ クラス の細街路が数多く形成されていることが分かる。4 $\mathrm{m}$ 未満の街路形成もわずかに見られるが、これは敷 地内の通路が住宅地図上では街路と見分けがつかず、 それが入力されたためと考えられる。したがって、 こうした街路は市街化した敷地の一部と見なせる。 


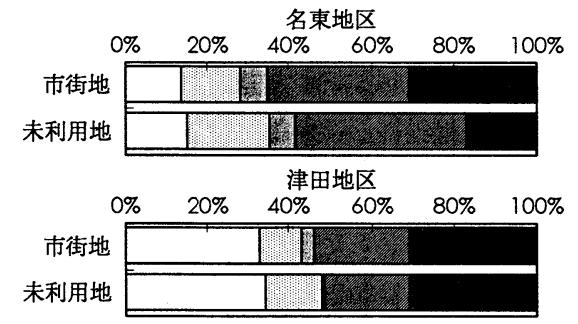

口0-2.7回2.7-3.6圈3.6-4.0圈4.0-6.0口6.0- 幅員 (m) 図-7 前面街路幅員ランク別土地面積構成比

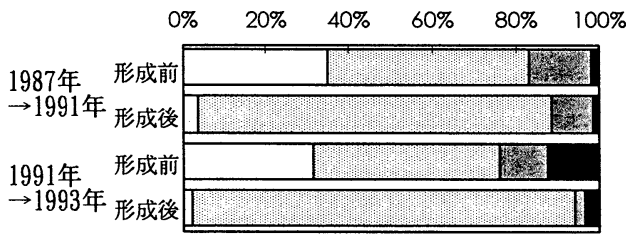

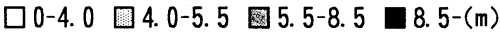
図一8 街路形成の有った土地の前面街路幅員別比率 (名東)

\section{(4)孤立幅員}

災害時などにおける街路の性能から、各ピクセル の安全性を示す指標として、孤立幅員指標を考案し た。孤立幅員とは、「あるリンクから最寄りの幹 線街路へ出るすへてての経路を探索し、各経路の最小 幅員の最大値」のことである1)。すなわち、地区外部 への車両通行経路上のボトルネックになる街路の幅 員である。各ピクセルの孤立幅員は、前面街路の孤 立幅員を用いる。

幅員 $4 \mathrm{~m}$ の街路の場合、普通車が駐車していると 大型の緊急車両は通行不能になる。したがって、孤 立幅員が $4 \mathrm{~m}$ 以下のピクセルでは、幹線街路からの 緊急車両のアクセスに対する信頼性が低いと考えて、 このようなピクセルの空間位置を分析した。その例 を図ー9に示す。スプロール中期段階の矢三地区の 場合、孤立幅員 $4 \mathrm{~m}$ 以下のピクセルは内部に点在し ていることがわかる。図-10は、1991年時の孤立幅 員ランク別の土地面積構成比を示した例である。孤 立幅員 $4 \mathrm{~m}$ 未満の問題未利用地は、密集市街地であ る津田地区よりむしろスプロール進行中の矢三地区 の方が多いことがわかる。図-11は、孤立幅員 $4 \mathrm{~m}$ 以下を問題として、横軸に問題となる未利用地、縦 軸に問題となる市街地のそれぞれの面積の全土地面 積に対する割合をとりプロットしたものである。矢 三、名東とも未利用地は減少傾向にあるが、市街地

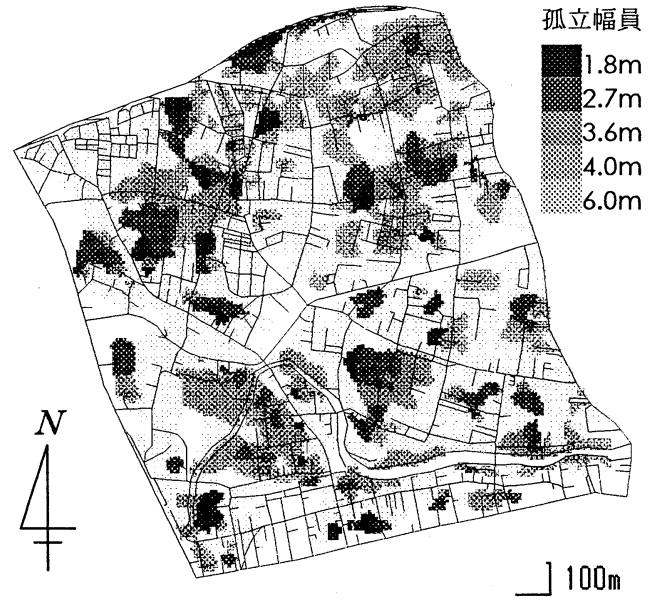

図ー9 孤立幅員ランク別ピクセル空間分布（矢三1991）

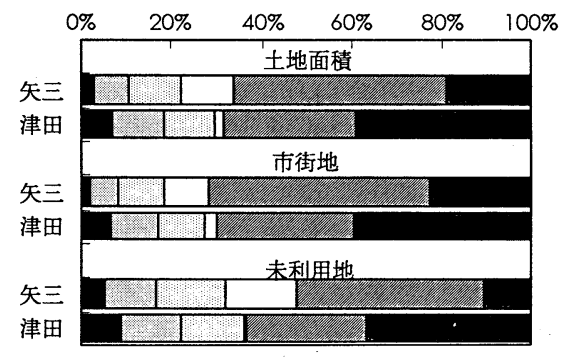

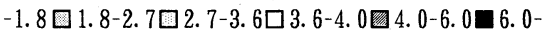
孤立幅員 (m)

図一10 孤立幅員ランク別土地面積構成比

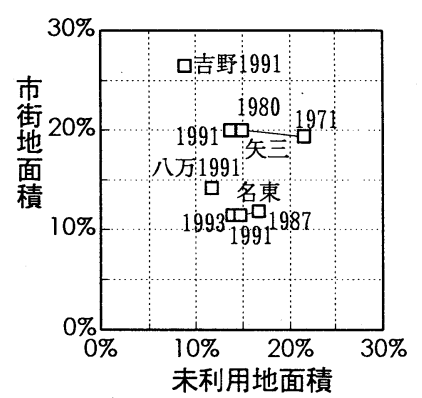

図一11 地区面積に対する土地面積割合 （孤立幅員 $4 \mathrm{~m}$ 以下）

はスプロール初期の名東では減少し、進行段階の矢 三では逆に増加傾向にあることがわかる。

表一 4 は、スプロール進行段階の矢三地区におけ る1980年から1991年にかけてのピクセルの孤立幅員 の変化と市街化および変化なしの間の関連を示した 例である。なお、都市的未利用地からそれ以外への 変化をここでは市街化と呼ぶ。これによると、対角 
線上の幅員ランク変化がないピクセルは多いが、僅 かながら孤立幅員 $4 \mathrm{~m}$ 以上から問題ピクセルへと幅 員ランクが逆に低下しているピクセルが見られる。 ある孤立幅員を持つリンクに街路が接続した場合、 その街路の幅員が接続したリンクの孤立幅員より広 ければ、もとのリンクの孤立幅員がその街路の孤立 幅員になる。このようにして問題孤立幅員を持つ経 路上に細街路が形成されたために、幅員ランクの低 下が生じていると考えられる。

表一 5 は、同じ矢三地区における1980年から1991 年にかけての孤立幅員ランクの変化とこうした街路 形成との関連を示した例である。これによると、街 路形成ピクセル（）は孤立幅員 $4 \mathrm{~m}$ 前後に多く、 それは1980年時点の全てのランクに見られる。しか し、わずかながら孤立幅員が減少したピクセルも見 られる。これは、表-4の場合と同様に、街路形成 前に比べ狭い孤立幅員を持つ経路上に街路が形成さ れたためと考えられる。さらに、ピクセル周辺に街 路形成がないにも関わらず孤立幅員が変化している ピクセルがいくらか見られる。これは、当該ピクセ ルとは関係ないところでの街路形成が幹線街路への アクセス経路を変化させ、その影響で当該ピクセル の孤立幅員が変化したものと考えられる。

\section{(5)消防活動困難区域}

消防対策として街路整備を行う場合の消防活動が 困難な区域 (消防活動困難区域)の選定基準は、「現 況幅員 $6 \mathrm{~m}$ 以上の道路から直距離で $140 \mathrm{~m}$ の範囲に含 まれない区域で消防活動が困難な区域」とされてい $ろ^{2)}$ 。「直距離で $140 \mathrm{~m}$ の範囲」とは、図ー12に示す ように、消防車停車位置から地区内部へ $200 \mathrm{~m}$ のホー スで街路等を通って到達できる範囲のことを意味し ている。市街化の進んでいない地域の場合、田畑・ 空き地などは細街路と同じようにホースの通路とし て使えることから、消防活動困難区域は「現況幅員 6 $\mathrm{m}$ 以上の道路から $200 \mathrm{~m}$ のホースで㞬き地や道路を通 り到達できない区域」と解釈することができる。

本システムでは「孤立幅員 $6 \mathrm{~m}$ 以上のリンクから 各ピクセルまで、未利用地ピクセルか街路を伝って 進んだときの距離（到達距離と呼ぶ）」を各ピクセ ルの隣接関係を探索し(1)求めた。そして、その距離 が200mを越えるピクセルを消防活動困難区域として

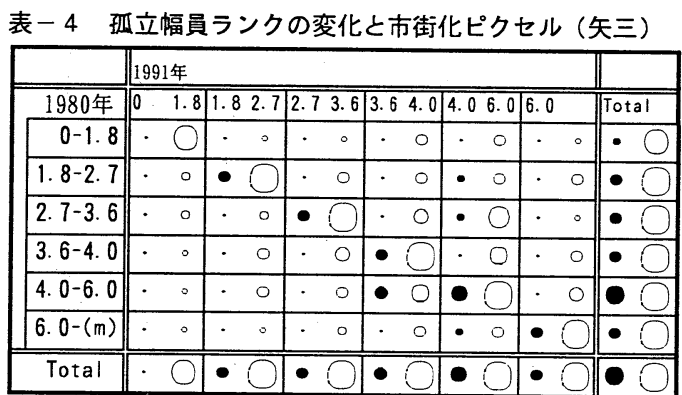

$\begin{array}{rcccccccc}\text { ピクセル数 } & 0 & 5 & 20 & 60 & 125 & 250 & 500 & 1000 \\ \text { 市街化 } & \cdot & \bullet & \bullet & \bullet & 0 & 0 & 0 & 0 \\ \text { 変化なし } & 0 & 0 & 0 & 0 & 0 & 0 & 0 & 0\end{array}$

表－5 孤立幅員ランクの変化と街路形成（矢三）

\begin{tabular}{|c|c|c|c|c|c|c|c|}
\hline & \multicolumn{6}{|l|}{1991 年 } & \\
\hline 1980年 & $\begin{array}{ll}0 & 1.8 \\
\end{array}$ & 1.82 .7 & 2.73 .6 & 3.64 .0 & 4.06 .0 & 6.0 & Total \\
\hline $0-1.8$ & $\cdot 0$ & . 0 & & - 0 & - 0 &.$\quad \circ$ & 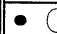 \\
\hline $1.8-2.7$ & . 0 & $\cdot 0$ & . 0 & - 0 & - 0 & $\cdot 0$ & \\
\hline 2. $7-3.6$ & o & $\circ$ & $\cdot 0$ & - 0 & 0 & . & \\
\hline $3.6-4.0$ & . 0 & .0 & - 0 & - O & - 0 & . 0 & $\bullet$ \\
\hline 4. $0-6.0$ & 。 & . 0 & .0 & 0 & 0 & - 0 & \\
\hline 6. $0-(\mathrm{m})$ & 。 & 。 & - 0 & & & $\bullet$ & \\
\hline Total & $\cdot \bigcirc$ & $\bullet$ & - & & & & \\
\hline
\end{tabular}

$\begin{array}{ccccccccc}\text { ピクセル数 } & 0 & 5 & 20 & 60 & 125 & 250 & 500 & 1000 \\ \text { 街路形成 } & \bullet & \bullet & \bullet & \bullet & \bullet & 0 & 0 & 0 \\ \text { 形成なし } & 0 & \circ & \bullet & 0 & 0 & 0 & 0 & 0\end{array}$

算出した。孤立幅員 $6 \mathrm{~m}$ 以上という条件は、幹線街 路から幅員 $6 \mathrm{~m}$ 以上の街路だけを通って到達できる 街路に限定することになる。図ー13は、スプロール 進行段階の矢三地区において、この到達距離をもと に消防活動困難区域を示したものである。到達不能 ピクセルとは、ピクセル周辺のいかなる街路からも 市街地を通らなければ到達できないピクセルである。 図-14は、消防活動困難区域の土地面積の年次変化 を、横軸に未利用地、縦軸に市街地のそれぞれの面 積の全土地面積に対する割合をとりプロットしたも のである。それぞれスプロール初期・中期・後期の 名東、矢三、沖洲ともに消防活動困難区域にある市 街地は增加していることがわかる。さらに、困難区 域面積の年次変化の傾きが市街化の発展段階によっ て異なっていることがわかる。こ机は、市街化が進 行し建て詰まって来るにつれ、困難区域内の土地が 市街化されたためと考えられる。

表- 6 は、スプロール初期段階の名東地区の 1987 年から1991年にかけての到達距離ランクの変化と市 
街化との関連を示したものである。1987年時点の到 達距離 $200 \mathrm{~m}$ 以内のピクセルのうち 1991 年時点に到達 不能の土地で市街化したピクセルが存在しているこ とがわかる。

\section{(6)狭险袋小路の分布}

袋小路は、災害時の多方向避難や円滑な消火活動 などに対して問題を有する場合がある。一般に消火 活動や避難時の安全性から消火栓の設置できない 4 $\mathrm{m}$ 末満の袋小路の延長が $50 \mathrm{~m}$ を越える場合、防災 上望ましくないとされている3)。そこで、前節に示し た消防活動困難区域では把握することのできないこ うした狭隘な袋小路の分布やそこに面する土地につ いて分析を行う。

ここでは、「リンクの行き詰まり点を示すノード から 3 分岐以上の交差点にあたるまでリンク」を袋 小路と定義して、ネットワークにより袋小路を探索 した。図ー15は、こうした防災上問題のある土地を ピクセルの空間分布で表した例である。袋小路リン クを前面街路とするピクセルについて袋小路入口か らピクセル中心までの距離別に示したものである。 またリンクは、袋小路街路の幅員別に表してある。 これによると、消防活動困難区域の $6 \mathrm{~m}$ 街路から 1 〜 2 交差点以上奥まったところで問題ピクセルが見 られる。

図－16は、問題袋小路に面する土地面積の全土地 面積に対する割合の年次変化を示したものである。 名東・矢三地区とも市街化の進行に伴い問題ピクセ ルは隇少傾向にあることがわかる。

\section{4.おわりに}

本研究では、街路周辺の土地の地理的構造をピク セルの集合としてとらえ、土地利用や施設の情報を ピクセルの属性として扱うことで、周辺市街地を考 虑した住区内街路網評価を簡便に行うシステムを開 発した。そして、このシステムの住区内街路網評価 への適用事例として、徳島市内の非計画的市街地の 細街路網を防災性の視点から実態分析を試みた。

具体的には、ピクセル前面街路幅員や孤立幅員、 $6 \mathrm{~m}$ 街路からの到達距離および前面街路の袋小路と いったピクセルごとの指標値をこのモデルを用いて 算定した。この結果、問題ピクセルの空間分布を明

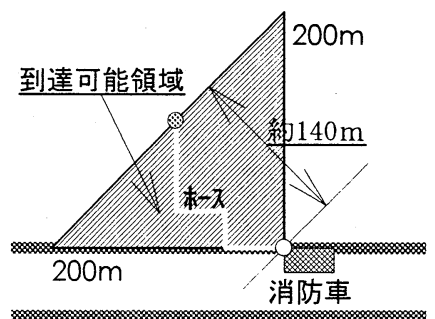

図-12 140mの意味

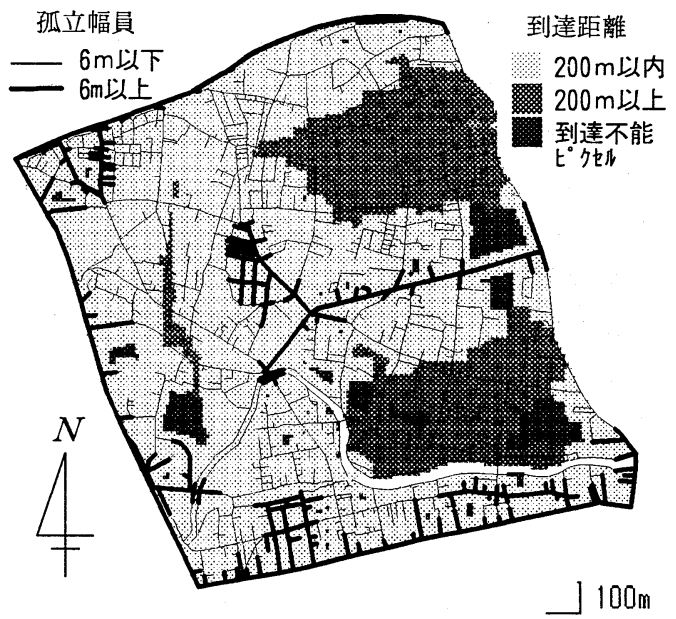

図-13 消防活動困難区域（矢三1991）

表 -6 到達距離ランク変化と市街化との関連（名東）

\begin{tabular}{|c|c|c|c|c|c|c|}
\hline \multirow{2}{*}{\multicolumn{2}{|c|}{$\begin{array}{l}\text { 孤立幅員 } \\
6 \mathrm{~m} \text { 街路からの } \\
\text { 到達距離 }\end{array}$}} & \multicolumn{5}{|l|}{ 1991年 } \\
\hline & & $\begin{array}{c}6 \mathrm{~m} \\
\text { 上 }\end{array}$ & $\begin{array}{l}0- \\
200\end{array}$ & 200 & $\begin{array}{l}\text { 不 } \\
\text { 能 }\end{array}$ & Total \\
\hline | & $6 \mathrm{~m}$ 街路上 & - 0 & 。 & . & . & • \\
\hline 9 & $0-200$ & 。 & - 0 & - $\quad 0$ & $\bullet$ & 0 \\
\hline 8 & $200-(\mathrm{m})$ & $\cdot$ & $\cdot$ & - 0 & $\cdot$ & $\bullet$ \\
\hline 7 & 到達不能 & 。 & · & $\circ$ & $\cdot 0$ & \\
\hline & Total & - 0 & - 0 & - & - 0 & \\
\hline
\end{tabular}

$\begin{array}{rcccccccc}\text { ピクセル数 } & 0 & 5 & 20 & 60 & 125 & 250 & 500 & 1000 \\ \text { 市街化 } & \cdot & \bullet & \bullet & \bullet & \bullet & 0 & 0 & 0 \\ \text { 変化なし } & 0 & 0 & 0 & 0 & 0 & 0 & 0 & 0\end{array}$

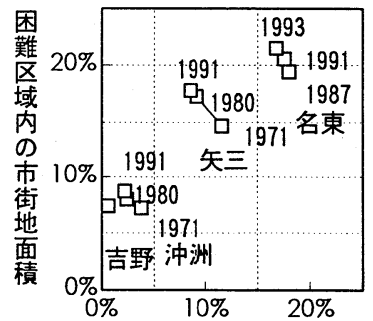

困難区域内の未利用地面積

図一14 地区面積に対する消防活動困難区域の割合 
確にし、また街路周辺の市街地や未利用地といった 土地種別ごとに集計することでその面積を算定する ことができた。さらに、各ピクセルごとに市街化や 周辺細街路形成を判断することで、市街地形成や細 街路形成といった地区の動きについても捉えられる ことができた。

残された課題としては、システムについては面積 などの計算精度とピクセルサイズの関連について分 析することで、適切なサイズを検討する必要がある。 また、代替案作成やその評価の各プロセスでの活用 の方法を検討することも重要である。具体的には、 地区内街路網の実態を把握することで得られた結果 をもとに、それらを統合し市街化段階の違いや市街 地形成および細街路網形成が地区防災性に及ぼす影 響について分析することで、細街路網整備方針の検 討を行うとともに、その整備効果について評価する ことが必要と考えられる。

\section{補注}

(1)孤立幅員 $6 \mathrm{~m}$ 以上の街路上のピクセル全てについて、 隣接するピクセルのうち、未利用地ピクセルもしくは 細街路でつながるピクセルを探索し、これを 1 ピクセ ル $(10 \mathrm{~m})$ で到達可能な範囲とする。この操作を上記 ピクセル群について繰り返せば、孤立幅員 $6 \mathrm{~m}$ 以上の 街路から $200 \mathrm{~m}$ (20 ピクセル) で到達可能な範囲を求 めることができる。

参考文献

1)藤原・山中・三谷・永峯：「ネットワーク特性に着目し た狭湓道路の実態分析」, 土木学会中国四国支部第 46 回研究発表会講演概要集, pp. 526-527, 1994.

2)防災まちづくり研究会：「防災まちづくりハンドブッ

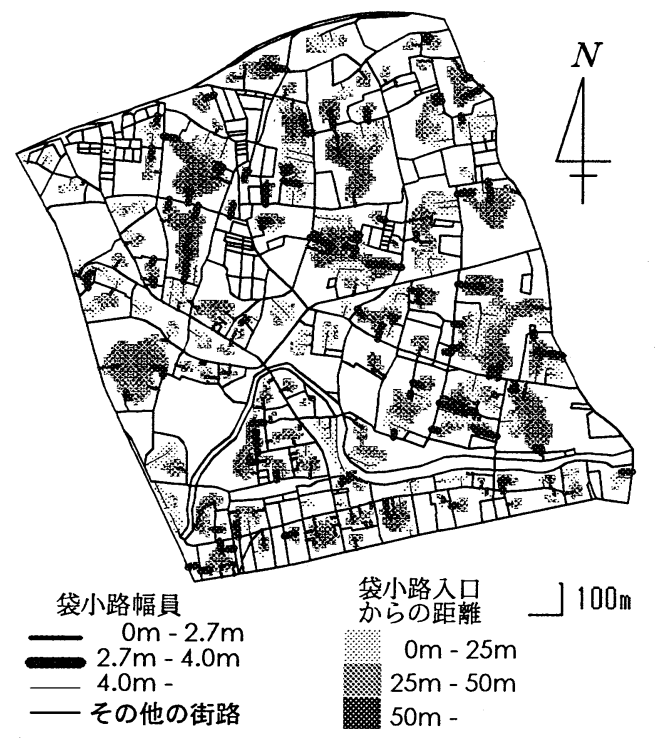

図ー15 問題袋小路に面するピクセル空間分布 (矢三1991)

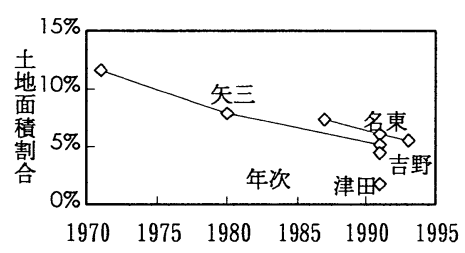

図-16 問題袋小路に面する土地面積割合の年次変化

ク」,ぎうせい, p84, 1988.

3) 三船・山田・ 小出: 「低層高密度市街地の『計画最小単 位』に関する研究－消防活動困難区域の解決に向けて 一」, 第 26 回日本都市計画学会学術研究論文集, No26-B, pp589-594, 1991.

ネットワーク・ピクセルアレイ型の地理情報を用いた住区内街路網評価システム

三谷哲雄・山中英生・青山吉隆

住区内街路網評価では、街路レベルの交通安全性や道路環境評価とともに、街路沿道の宅地レベルの市街地 形成への影響や住環境の評価が必要となる。交通ネットワーク分析のように交通ゾーンとネットワーク構造を 用いた分析では、リンク後背市街地の地理的構造を考虑する必要がある。しかし、こうした土地形状をポリゴ ンテータとして扱う場合、複雑な幾何計算を要する。そこで、周辺市街地の地理的構造を細かなピクセルの集 合として捉えることで、ネットワークを街路周辺市街地の視点から簡便に評価するシステムを開発した。そし て、徳島市の非計画的市街地における細街路網評価をこのシステムを用いて行った場合の計算方法や結果の例 を示す。

\section{Analysis System for Residential Street Networks \\ Using the Geographical Database of Network and Pixel-Array Model}

Tetsuo MITANI, Hideo YAMANAKA and Yoshitaka AOYAMA

This study aims to develop evaluation methods for urban street networks in spread residential areas, from the viewpoint of disaster prevention. A geographical database system is developed based on the network and pixel array model. By employing the analysis system for this database, local street networks of residential districts are evaluated through the street network indices from the viewpoint of disaster prevention. Using this model to represent streets and land use, both the locations and numbers of problematic residential lots can easily be found. 